\title{
Bioactive Electrospun Scaffolds Delivering Growth Factors and Genes for Tissue Engineering Applications
}

\author{
Wei Ji • Yan Sun • Fang Yang •Jeroen J. J. P. van den Beucken • Mingwen Fan • Zhi Chen • John A. Jansen
}

Received: 30 August 2010 / Accepted: 3 November 2010 / Published online: 19 November 2010

(C) The Author(s) 2010. This article is published with open access at Springerlink.com

\begin{abstract}
A biomaterial scaffold is one of the key factors for successful tissue engineering. In recent years, an increasing tendency has been observed toward the combination of scaffolds and biomolecules, e.g. growth factors and therapeutic genes, to achieve bioactive scaffolds, which not only provide physical support but also express biological signals to modulate tissue regeneration. Huge efforts have been made on the exploration of strategies to prepare bioactive scaffolds. Within the past five years, electrospun scaffolds have gained an exponentially increasing popularity in this area because of their ultrathin fiber diameter and large surface-volume ratio, which is favored for biomolecule delivery. This paper reviews current techniques that can be used to prepare bioactive electrospun scaffolds, including physical adsorption, blend electrospinning, coaxial electrospinning, and covalent immobilization. In addition, this paper also analyzes the existing challenges (i.e., protein instability, low gene transfection efficiency, and difficulties in accurate kinetics prediction) to achieve biomolecule release from electrospun scaffolds, which necessitate further research to fully exploit the biomedical applications of these bioactive scaffolds.
\end{abstract}

KEY WORDS electrospinning · gene delivery · protein delivery. scaffold $\cdot$ tissue engineering

W. Ji $\cdot$ Y. Sun $\cdot$ F. Yang $\cdot$ J. J. J. P. van den Beucken · J. A. Jansen $(\bowtie)$ Department of Biomaterials (Dentistry 309)

Radboud University Nijmegen Medical Center

PO Box 9I0I, 6500 HB, Nijmegen, The Netherlands

e-mail: J.Jansen@dent.umcn.nl

W. Ji $\cdot$ Y. Sun $\cdot$ M. Fan $\cdot$ Z. Chen

Key Laboratory for Oral Biomedical Engineering of Ministry of

Education, School and Hospital of Stomatology, Wuhan University

237 Luoyu Road

430079, Wuhan, Hubei Province, People's Republic of China

\begin{tabular}{|c|c|}
\hline \multicolumn{2}{|c|}{ ABBREVIATIONS } \\
\hline ALP & alkaline phosphatase \\
\hline BMP2 & $\begin{array}{l}\text { bone morphogenic protein } \\
2 \text { (protein form) }\end{array}$ \\
\hline bmp2 & $\begin{array}{l}\text { bone morphogenic protein } \\
2 \text { (gene form) }\end{array}$ \\
\hline BSA & bovine serum albumin \\
\hline EGF & epidermal growth factor \\
\hline FA & folic acid \\
\hline $\mathrm{HA}$ & hyaluronic acid \\
\hline HAp & hydroxylapatite \\
\hline NGF & nerve growth factor \\
\hline pBMP-2 & $\begin{array}{l}\text { plasmid DNA encoding bone } \\
\text { morphogenic protein-2 }\end{array}$ \\
\hline PCL & poly(E-caprolactone) \\
\hline PCL-b-PEG & $\begin{array}{l}\text { poly(E-caprolactone)-block-poly(ethylene } \\
\text { glycol) }\end{array}$ \\
\hline pCMV-EGFP & $\begin{array}{l}\text { plasmid DNA encoding enhanced } \\
\text { green fluorescent protein with a } \\
\text { cytomegalovirus promoter }\end{array}$ \\
\hline$p C M V \beta$ & plasmid DNA encoding $\beta$-galactosidase \\
\hline PDGF-bb & platelet-derived growth factor-bb \\
\hline PDLLA & poly (D,L-lactide) \\
\hline pDNA & plasmid deoxyribonucleic acid \\
\hline PEG-b-PDLLA & poly (ethylene glycol)-block-poly(D,L-lactide) \\
\hline pEGFP-NI & $\begin{array}{l}\text { plasmid DNA encoding a red shifted } \\
\text { variant of wild-type green } \\
\text { fluorescent protein }\end{array}$ \\
\hline pGL3 & plasmid DNA encoding luciferase \\
\hline PLCL & poly(L-lactide-co-epsilon-caprolactone) \\
\hline PLGA & poly(lactide-co-glycolide) \\
\hline PMMAAA & $\begin{array}{l}\text { copolymer of methyl methacrylate } \\
\text { (MMA) and acrylic acid (AA) }\end{array}$ \\
\hline PSU & polysulphone \\
\hline PVA & poly(vinyl alcohol) \\
\hline
\end{tabular}




\section{INTRODUCTION}

Tissue engineering is an interdisciplinary field that applies the principles of engineering and life sciences toward the development of functional substitutes for damaged tissues. The fundamental concept behind tissue engineering is to utilize the body's natural biological response to tissue damage in conjunction with engineering principles (1). To achieve successful tissue regeneration, three key factors are to be considered: cells, scaffolds, and biomolecules (e.g., growth factor, gene, etc.). Currently, two strategies have emerged as the most promising tissue engineering approaches (Fig. 1) (2). One is to implant pre-cultured cells and synthetic scaffold complexes into the defect place. In this approach, the seeded cells are generally isolated from host target tissues, for which they provide the main resource to form newly born tissue. The synthetic scaffolds, on the other hand, provide porous three-dimensional structures to accommodate the cells to form extracellular matrix (ECMs) and regulate the cell growth in vivo $(3,4)$. These synthetic scaffolds are biodegradable and degrade in accordance with the tissue regeneration time frame. The other approach is to place acellular scaffolds immediately after injury. The governing principle of this approach is using scaffolds to deliver appropriate biomolecules to the defect area; the biomolecules are released from the scaffolds in a controlled manner and may recruit progenitor cells toward the defect area and promote their proliferation and differentiation, thereby enhancing tissue regeneration.
In recent years, an increasing trend toward the combination of these two approaches is observed (5-8), because the scaffolds with controlled release of biomolecules can induce the seeded cells to proliferate and differentiate during an ex vivo pre-culture period, thereby encouraging tissue formation after implantation in vivo. Meanwhile, the scaffolds will continue to release signal molecules after implantation to enhance the desired physiological response and, consequently, enhance tissue regeneration in the defect area. In view of these strategies, to achieve successful and efficient tissue engineering, an increasing demand exists for bioactive scaffolds that can provide more than only physical support for cells but also a local release of bimolecules to influence surrounding tissue regeneration. This type of scaffold is termed "bioactive scaffold" (1).

The importance of bioactive scaffolds in tissue engineering has been comprehensively reviewed (9). Various biomolecules can be incorporated within tissue-engineered scaffolds to enhance their functional properties for biomedical applications. The most frequently used biomolecules are proteins (e.g., growth factors or cytokines) and growth factor coding genes. Growth factors $(\mathrm{GFs})$ are endogenous proteins capable of binding cell-surface receptors and directing cellular activities involved in the regeneration of new tissue (10). Localized delivery of exogenous GFs is suggested to be therapeutically effective for production of cellular components involved in tissue development and the healing process, thus making them important factors for tissue regeneration (11). Nevertheless, it has to be empha- a

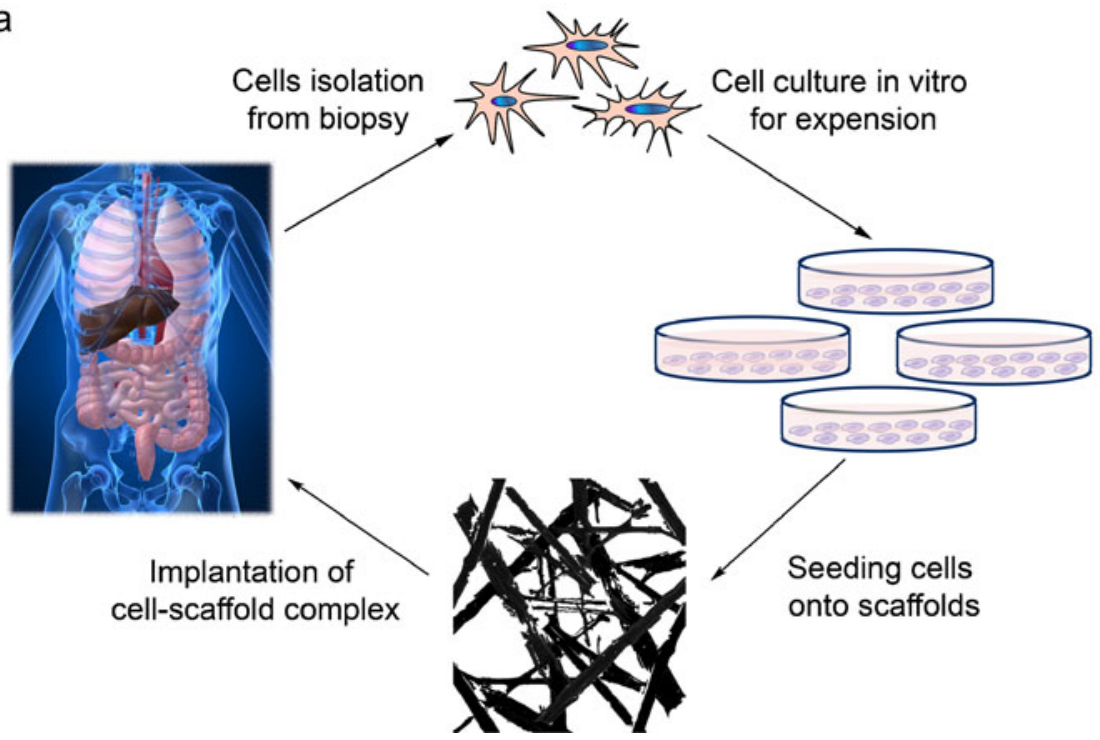

b

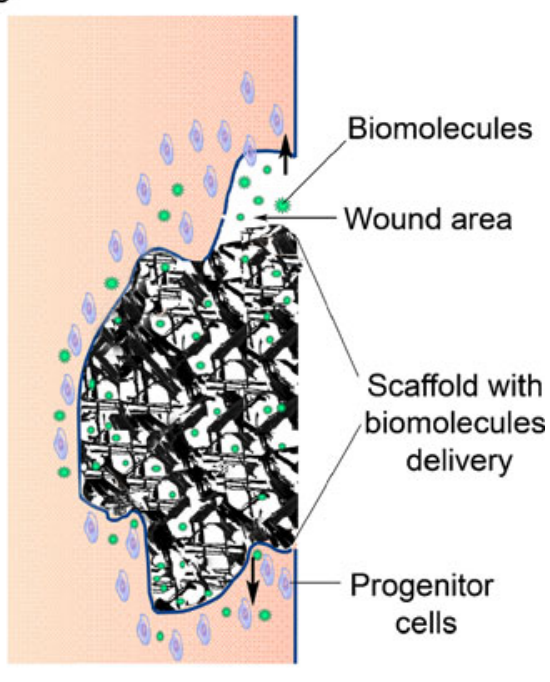

Fig. I Current tissue engineering approaches. a To implant pre-cultured cells-scaffolds complex into the defect place, cells are isolated from biopsy and then cultured in vitro for expansion. Then the cells are seeded onto synthetic scaffolds, which provide a porous three-dimensional structure to accommodate seeding cells to form extracellular matrix; $\mathbf{b}$ to place acellular scaffolds with biomolecules delivery immediately after injury, the biomolecules are released from scaffolds in a controlled manner, and they may recruit the progenitor cells in wound area and promote their proliferation and differentiation. 
sized that the success of direct growth factor delivery from scaffolds depends on the large-scale production of recombinant GFs, which is quite expensive. Additionally, protein bioactivity after incorporation within scaffolds also needs to be considered in view of efficacy issues. Instead of growth factor delivery, gene therapy presents a new paradigm in tissue engineering. This concept gives birth to gene-activated scaffolds (GASs), which are defined as scaffolds incorporating therapeutic protein-encoding genes (12). GASs ensure the delivery of genes at the desired site (13), after which transfection into target cells is required to produce therapeutic proteins (14). Compared to growth factor delivery, gene delivery is advantageous in its long-term effect as well as relatively low cost, which makes it promising for tissue engineering application.

Since the last decade, huge efforts have been made to explore strategies for the preparation of bioactive scaffolds to deliver therapeutic proteins or genes, and a series of comprehensive reviews has provided detailed information for these strategies (14-16). In general, proteins or genes can be delivered by micro/nano-particles (17), hydrogels (18) or electrospun fibrous matrices (19,20). For micro/ nano-particles, due to their fluidity, it is difficult to keep them localized in the defected area to give new tissues enough support (21). Therefore, such particles can only be used as carriers for biomolecules rather than scaffolds for tissue engineering. Comparably, hydrogels have been used as drug delivery systems for many years, but the poor mechanical properties of hydrogel-based scaffolds limits their use for load-bearing applications, and this disadvantage can even result in the premature dissolution or displacement of the hydrogel from a targeted local site (22). Electrospinning is a popular technique to prepare tissue engineering scaffolds due to its relative simplicity regarding the generation of fibrous scaffolds with nano- or submicron-scale dimensions, which morphologically resemble the natural ECM. Due to the possibility of ultrathin fiber diameters, electrospun fibrous matrices can have a large specific surface area, which enables effective delivery of biomolecules. Furthermore, the loose bonding between fibers is beneficial for tissue growth and cell migration (23). These characteristics endue electrospinning with superiority in preparation of bioactive scaffolds. In 2003, electrospinning was first used to prepare bioactive scaffolds with gene release (24), and, thereafter, this technique has gained exponentially increasing popularity in this area (Fig. 2). The aim of this paper is to review the techniques to incorporate growth factors or genes into electrospun scaffolds. Additionally, the existing challenges of using electrospinning in the area of tissue regeneration will be discussed.

\section{BASICS RELEVANT TO ELECTROSPINNING}

Electrospinning is a cost-efficient technique to prepare ultrafine polymeric fibers, which can be easily employed in the laboratory and scaled up to an industrial process. It utilizes electrostatic forces to spin polymer solutions or melts into whipped jets, resulting in continuous fibers with diameters from a few nanometers to micrometers after solvent evaporation in the spinning process $(25,26)$. A typical electrospinning apparatus consists of four major components: (1) a syringe pump, which controls the feeding rate of polymer solution to be electrospun; (2) a needle, through which the solution goes into a high electric field; (3) a high voltage source, which stretches the polymer solution into ultrathin fibers; and (4) a grounded fiber collector, where electrospun fibers can be collected in a static or dynamic way (Fig. 3).
Fig. 2 Publications and citations report from ISI web of Science ${ }^{\circledR}$, as of August 18, 2010.
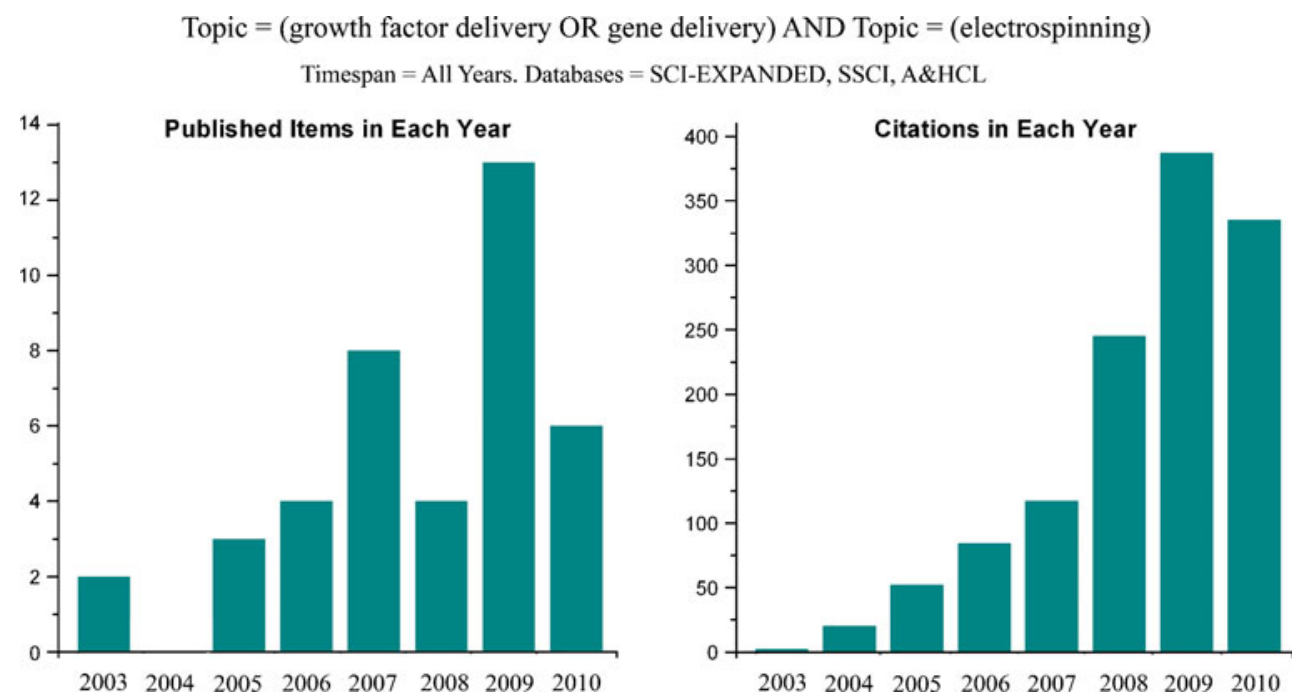


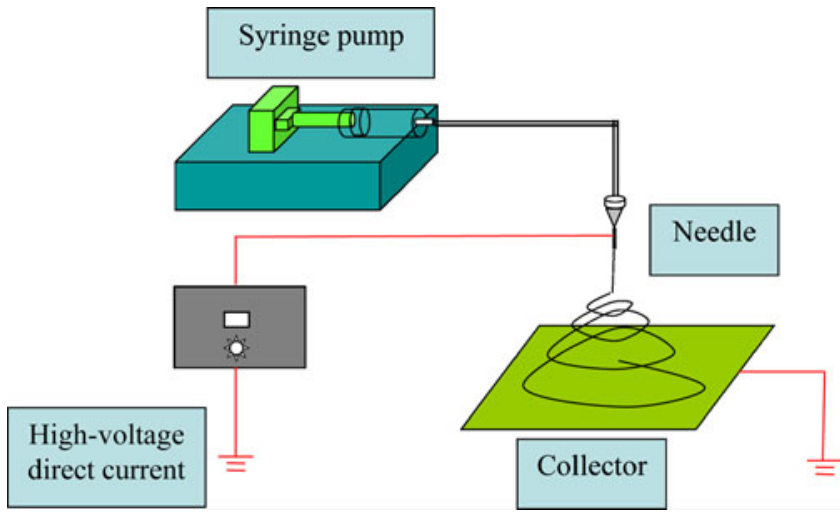

Fig. 3 Scheme for electrospinning apparatus.

The technique of electrospinning has been comprehensively reviewed $(25,27)$ : when high voltage is applied, the polymer solution droplet from the needle becomes highly electrified and tends to form a conical shape known as the Taylor cone, depending on the surface tension of the liquid and the force of electric field; once the electric field surpasses a threshold, the electric force overcomes the surface tension and viscoelastic force of the polymer droplet, which results in a finely charged jet from the tip of the Taylor cone; then, the jet sprays into one continuous ultrathin fiber. The random or aligned fibers can be collected on a grounded metallic collector in the form of a plate, cylinder or disc type (27). Based on this theory, it is clear that the electrospinning process can be manipulated by a number of variables. These variables include solution properties (polymer concentration, polymer moleculer weight), system set-up (applied voltage, feeding rate and collecting distance), and environmental factors (temperature and humidity) (20,25). Among these variables, solution properties are crucial for a succesful electrospinning. Further, literature indicates that low polymer weight, high fluidity or high density of the polymer solution will cause instabilities, including whipping and droplet instead of uniform fiber formation (28). In addition, sub-optimal voltage is another key factor that could lead to bead-like defects in the spun fibers or even failure in jet formation $(20,25)$.

There is a wide range of material choices to prepare electrospun scaffolds for tissue engineering applications, which mainly includes two categories: natural polymers and synthetic polymers. In principle, the material choice for scaffold preparation depends on the purpose of application and feasibility of electrospinning. Electrospun fibrous scaffolds prepared from natural polymers, especially collagen, are mostly used because these can mimic the properties of natural ECM for engineered tissues (29). However, some natural polymers are not easy to handle during electrospinning, as they tend to display poor processibility, which needs to be modified to achieve better electrospinning (30). Furthermore, it is difficult to confirm that native structure and biological characteristics of natural polymers are still preserved after electrospinning (31). In contrast, synthetic polymers (especially the polyesters) are much easier to be optimized for electrospinning process and, hence, are more commonly applied. Dong et al. (32) gave a comprehensive review listing different synthetic polymers that can be used to prepare electrospun scaffolds. Among multiple choices of synthetic polymers, poly ( $\varepsilon$-caprolactone) (PCL), poly(lactic acid) (PLA), poly(glycolic acid) (PGA) and their copolymers poly(lactic-co-glycolic acid) (PLGA) are most extensively used for biomedical applications because they are approved by the US Food and Drug Association (FDA) for their good biocompatibility as well as biodegradability.

\section{CURRENT PROGRESS OF ELECTROSPUN SCAFFOLDS WITH BIOMOLECULE DELIVERY}

\section{General Considerations for Growth Factor and Gene Delivery}

There are two important aspects to achieve a successful delivery: (1) to ensure the bioactivity of the biomolecules incorporated within the scaffolds and (2) to fit the release profile of biomolecules within the time-frame of tissue regeneration.

\section{Principles for Growth Factor Delivery}

Growth factors easily lose their activity upon chemical or physical processing. Therefore, the preservation of protein activity is a prerequisite for succucessful growth factor delivery. There are three stages during which the stability of a growth factor incorporated in a scaffold must be preserved: (1) scaffold fabrication, (2) scaffold storage, and (3) scaffold degradation. The source of the protein stability in each stage and available strategies to improve the protein stability will be explained in detail in "Protein Instability."

The release profile is another important issue to take into account when designing electrospun scaffolds to deliver growth factors. Considering that the half-lives of most growth factors in serum are very short, it is essential for bioactive scaffolds to maintain a desired temperospatial growth factor concentration to direct tissue regeneration. For this purpose, an optimal growth factor-delivering scaffold should be able to initially release part of the dosage contained, which is typically termed "burst release" (33), to rapidly get the effective therapeutic concentration. Subsequently, well-defined release kinetics follow in order to provide the maintenance dosage enabling the attainment of the desired concentration (34). 


\section{Principles for Gene Delivery}

Different from growth factors, which act extracellularly and initiate a biological response by binding to cell surface receptors, target genes will only have an intracellular effect by integrating into the host genome of endogenous cells and transforming the transfected cells into local bio-activated actors to enhance tissue formation. Consequently, a prerequisite for a successful gene delivery scaffold is that the active gene can be released from the scaffold, after which it needs to be integrated into the host genome. To achieve this goal, the target gene is always packed within vectors before it is incorporated into the scaffolds, because vectors can protect the target genes from extracellular DNA-degrading enzymes and intracellular lysosomes that contain digestive enzymes in the process of target gene being taken up by surrounding cells (13). On the other hand, vectors can transport genes through the lipid bilayer of the cell membrane, and the latter is the biggest obstacle in gene transfection. Currently, two categories of vectors are used: viral and non-viral vectors. The strategies of effective vectors have been clearly reviewed by Storrie et al. and Kootstra et al. (14,35).

Similar to growth factor delivery, an important issue for gene delivery is to modulate both the concentration and duration of the gene particles released from scaffolds, which dictates a well-controlled release profile. To achieve successful gene transfection, the effective concentration of target gene-vector complexes should be released into the cell-surrounding microenvironment within an optimal timeframe. It is found that a low concentration of DNA always results in low transfection efficiency $(36,37)$, and much too fast gene release leads to a low transfection efficiency, because superabundant gene complexes may lose activity if transfection is not achieved in due time (37).

\section{Fabrication Techniques for Electrospun Scaffolds with Biomolecule Delivery Capacity}

In general, biomolecules can be delivered either directly from the electrospun scaffolds or from additional separate release system (i.e., micro/nanospheres) loaded into the scaffolds, where the electrospun scaffolds behave only as a supporting structure. Since using micro/nano-spheres to deliver biomolecules has been comprehensively reviewed (38-41), this topic will not be addressed in this review. Different proteins and genes that have been loaded in electrospun scaffolds are listed in Tables I and II, respectively.

\section{Physical Adsorption}

The easiest way to load biomolecules into electrospun scaffolds is to dip the scaffolds into an aqueous phase containing biomolecules (Fig. 4a). In this approach, biomolecules can be in the form of pure solution or emulsions, and they can attach to the scaffolds via electrostatic forces. Although this approach gives little interference with the activity of loaded biomolecules, it is seldom used to load protein or genes in electrospun scaffolds due to the uncontrolled release profiles. It has been shown that bone morphogenic protein-2 (BMP2) adsorbed to PLGA scaffolds reached over $75 \%$ release within 5 days and nearly complete release within 20 days This release rate was much faster than that of the same amount of protein loaded in PLGA scaffolds using blend electrospinning (21). Similar evidence is available for gene delivery using this approach. Although some researchers could obtain transfected cells in an early stage (most likely due to a large amount of target gene bulk release $(36,37)$ ), the released gene exhausted within a short time, and over 95\% of incorporated DNA released within 10 days (37).

\section{Blend Electrospinning}

In blend electrospinning, biomolecules are mixed within the polymer solution, after which the mixed solution is used in the electrospinning process to fabricate a hybrid scaffold (Fig. 4b). Some researchers emphasized the preparing process of suspending the protein solution in polymer solution by emulsifying using ultra-sonication or homogenizer, therefore naming the process "emulsion electrospinning" (42). The idea for emulsification arises from the improvement of biomolecule suspension in organic solvents. Considering its same principle, we assume that it still belongs to blend electrospinning approach.

As blend electrospinning localizes biomolecules within the fibers of the scaffolds rather than simply adsorb them superficially to the scaffolds, it is assumed that this approach allows more sustained release profiles compared to physical adsorption. Researchers have used blend electrospinning to incorporate various types of proteins and genes in scaffolds, including bovine serum albumin (BSA) (43-45), lysozyme $(42,46)$ and growth factors (e.g., BMP2 (21,47), epidermal growth factor (EGF) (48). In general, a sustained release profile can be obtained over several weeks using this technique.

Although blend electrospinning is assumed to be relatively easy to perform, an inconvenient issue is the activity loss of incorporated biomolecules. This is especially vital for proteins, because they may lose their bioactivity due to conformational changes in the organic solution environment. On the other hand, the process to prepare protein emulsions, which involves mechanical stirring, homogenization or ultrasonication, can also damage protein function (49). In previous studies, several strategies have been applied to improve protein stability. A strategy is 
Table I Proteins that Have Been Loaded into Electrospun Scaffolds

\begin{tabular}{|c|c|c|c|c|}
\hline Fabrication technique & Loaded Protein & Scaffold material & Biological application & Reference \\
\hline \multirow[t]{2}{*}{ Physical adsorption } & BMP2 & PLGA & BMP2 release in vitro \& human bone marrow stem cell culture & $(21)$ \\
\hline & BMP2 & PLGA & Implantation of tibia defect in nude mice & $(54)$ \\
\hline \multirow[t]{9}{*}{ Blend electrospinning } & BSA & PEO & - & $(43)$ \\
\hline & BSA & PVA & $\mathrm{BSA}$ release in vitro & $(44)$ \\
\hline & BSA & PDLLA & BSA release in vitro \& structural integrity analysis & $(45)$ \\
\hline & lysozyme & PDLLA & Lysozyme release in vitro, structural integrity \& enzymatic analysis & $(42)$ \\
\hline & lysozyme & $\mathrm{PCL}$ & Lysozyme release in vitro \& enzymatic analysis & $(46)$ \\
\hline & bFGF & PLGA & $\begin{array}{l}\text { bFGF release in vitro \& rat bone marrow cell culture } \\
\text { to test bioactivity of released bFGF }\end{array}$ & $(67)$ \\
\hline & EGF & Silk fibroin & EGF release in vitro \& human dermal fibroblasts culture & $(48)$ \\
\hline & BMP2 & Silk fibroin & Human bone marrow stem cell culture & $(47)$ \\
\hline & BMP2 & PLGA & BMP2 release in vitro \& human bone marrow stem cell culture & $(21)$ \\
\hline \multirow[t]{8}{*}{ Coaxial electrospinning } & BSA & PCL & $\mathrm{BSA}$ release in vitro & $(61,62,64,68)$ \\
\hline & BSA & PLCL & BSA release in vitro & $(63)$ \\
\hline & lysozyme & PCL & Enzymatic analysis of released lysozyme & $(62)$ \\
\hline & PDGF-bb & $\mathrm{PCL}$ & NIH3T3 cell culture to test bioactivity of released PDGF-bb & $(64)$ \\
\hline & PDGF-bb & PLCL & $\begin{array}{l}\text { PDGF-bb release in vitro \& vascular smooth muscle } \\
\text { cells to test bioactivity of released PDGF-bb }\end{array}$ & $(65)$ \\
\hline & NGF & PLCL & $\begin{array}{l}\text { Rat pheochromocytoma cell line culture } \\
\text { to test bioactivity of released NGF }\end{array}$ & $(66)$ \\
\hline & bFGF & PLGA & $\begin{array}{l}\text { bFGF release in vitro \& rat bone marrow cell culture } \\
\text { to test bioactivity of released bFGF }\end{array}$ & $(67)$ \\
\hline & ALP & - & Enzymatic analysis of the post-electrospun ALP & $(68)$ \\
\hline \multirow[t]{5}{*}{ Covalent immobilization } & BSA & PEG-b-PDLLA & In vitro culture of human dermal fibroblast & $(89)$ \\
\hline & BSA & PCL/PCL-b-PEG mixture & In vitro culture of $\mathrm{NIH} 3 \mathrm{~T} 3$ cells & $(73)$ \\
\hline & EGF & PCL/PCL-b-PEG mixture & In vitro culture of human primary keratinocytes & $(74)$ \\
\hline & bovine collagen I & PMMAAA & In vitro culture of cortical neural stem cells & $(72)$ \\
\hline & BSA & PSU & - & $(75)$ \\
\hline
\end{tabular}

to use salt complexation instead of emulsification to improve protein solubility in organic solvents. Li et al. (46) incorporated lysozyme-oleate complex into electrospun membranes, and their results showed that the released lysozyme retained over $90 \%$ of bioactivity. Another strategy is to use hydrophilic additives to minimize the hydrophobic interaction of protein and organic solvents during electrospinning (50-52). It has been reported that hydrophilic polymers, such as poly(ethylene glycol) (PEG) and poly (ethylene oxide) (PEO) added in the aqueous protein

Table II Genes that Have Been Loaded into Electrospun Scaffolds

\begin{tabular}{|c|c|c|c|c|}
\hline Fabrication technique & Loaded gene particles & Scaffold material & Application & Reference \\
\hline \multirow[t]{2}{*}{ Physical adsorption } & pGL3 & PLA & Deliver gene into COS-7 cell line in vitro & $(90)$ \\
\hline & pBMP-2 & PLGA/HAp & Deliver gene into hMSC in vitro \& bone regeneration in nude mice & $(36,37)$ \\
\hline \multirow[t]{4}{*}{ Blend electrospinning } & pBMP-2 & PLGA/HAp & Deliver gene into hMSC in vitro \& bone regeneration in nude mice & $(36,37)$ \\
\hline & pBMP-2 & Silk/PEO/nHAp & Deliver gene into hMSCs in vitro for bone tissue engineering & $(47)$ \\
\hline & Adenovirus El & Chitosan/PEG/FA & Deliver gene into HEK293 cell line for cancer therapy & $(91)$ \\
\hline & $\mathrm{pCMV} \beta$ & PLA-PEG/PLGA & In vitro gene delivery into MC3T3-EI cell line & $(24,57)$ \\
\hline \multirow[t]{2}{*}{ Coaxial electrospinning } & pCMV-EGFP & PEI-HA/PCL & Non-viral gene delivery into CRL I 764 cell line in vitro & $(69)$ \\
\hline & Adenovirus EI/E3 & $\mathrm{PCL} / \mathrm{PEG}$ & Viral gene delivery into HEK293 cell line in vitro & $(70)$ \\
\hline Covalent immobilization & LPEI-pEGFP-NI & PCL-PEG & $\begin{array}{l}\text { Deliver gene into NIH3T3 cell line in vitro \& animal } \\
\text { study in vivo for local gene therapy of diabetic ulcers }\end{array}$ & $(7 \mid)$ \\
\hline
\end{tabular}


a

- Polymer solution

- Biomolecule solution
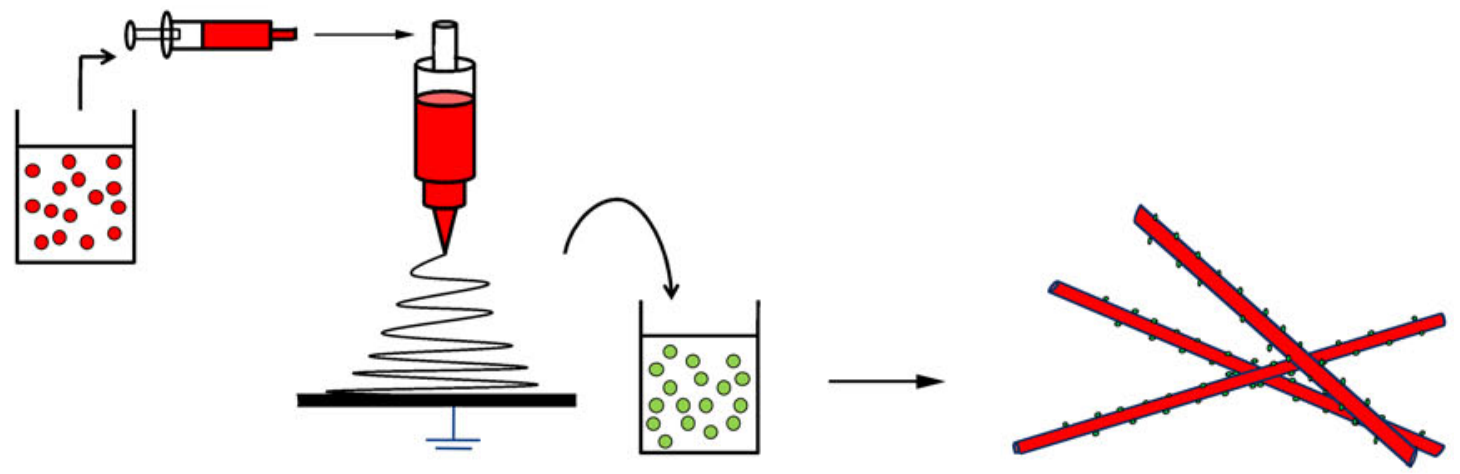

b
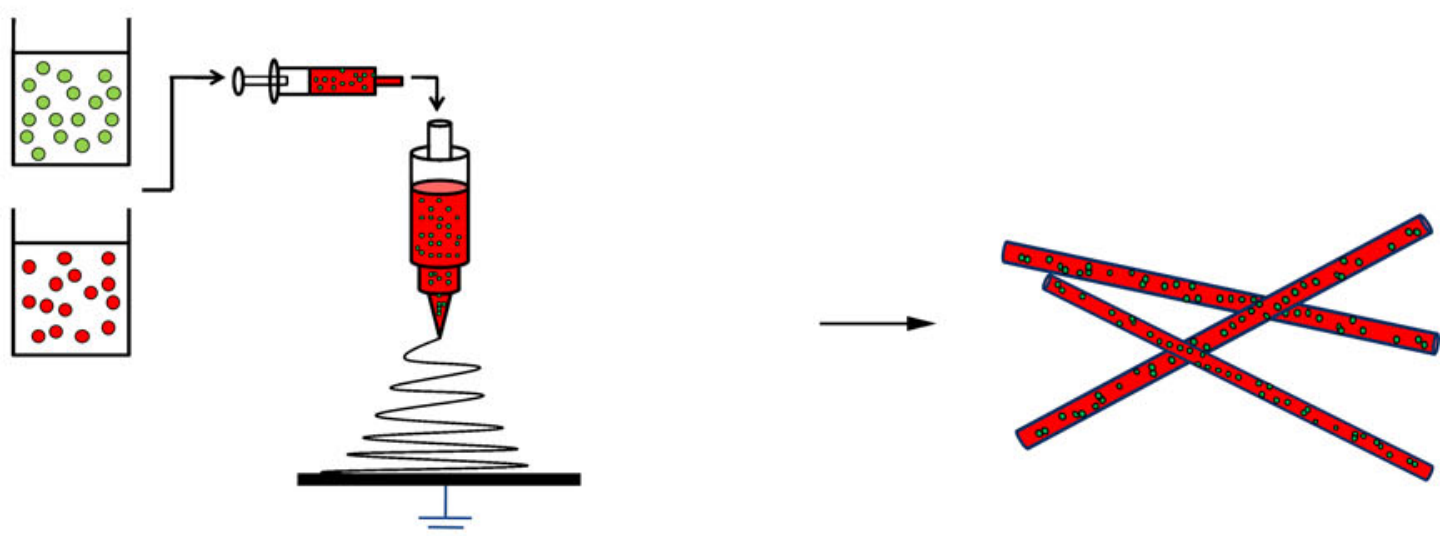

c
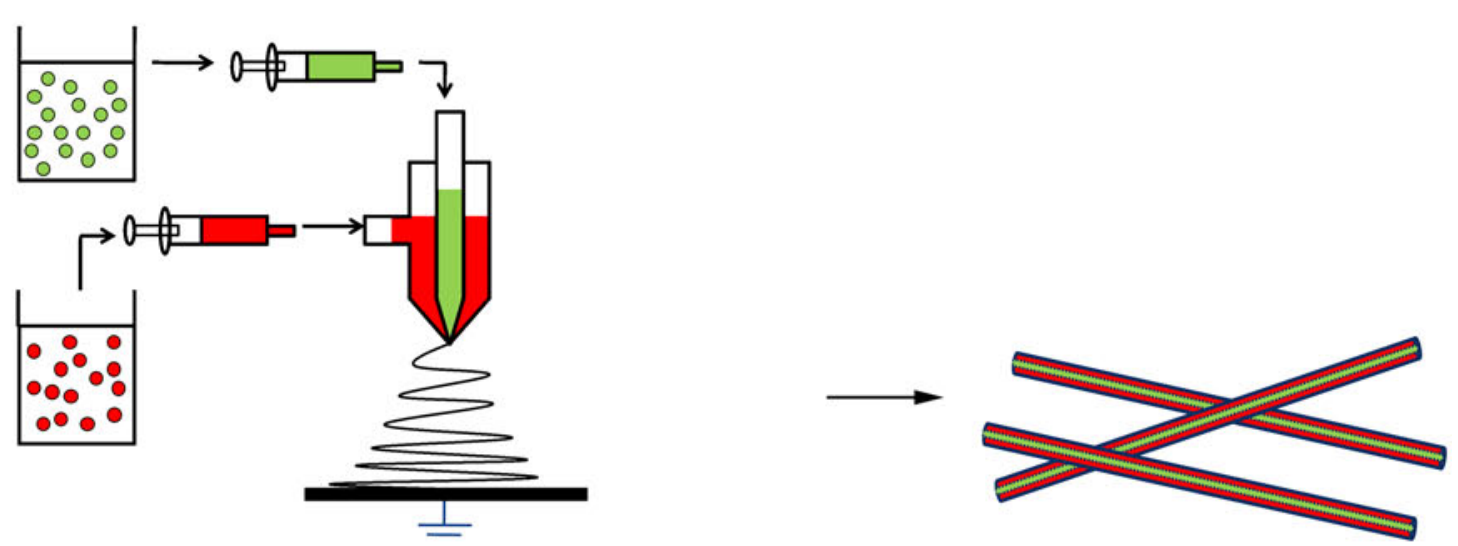

d
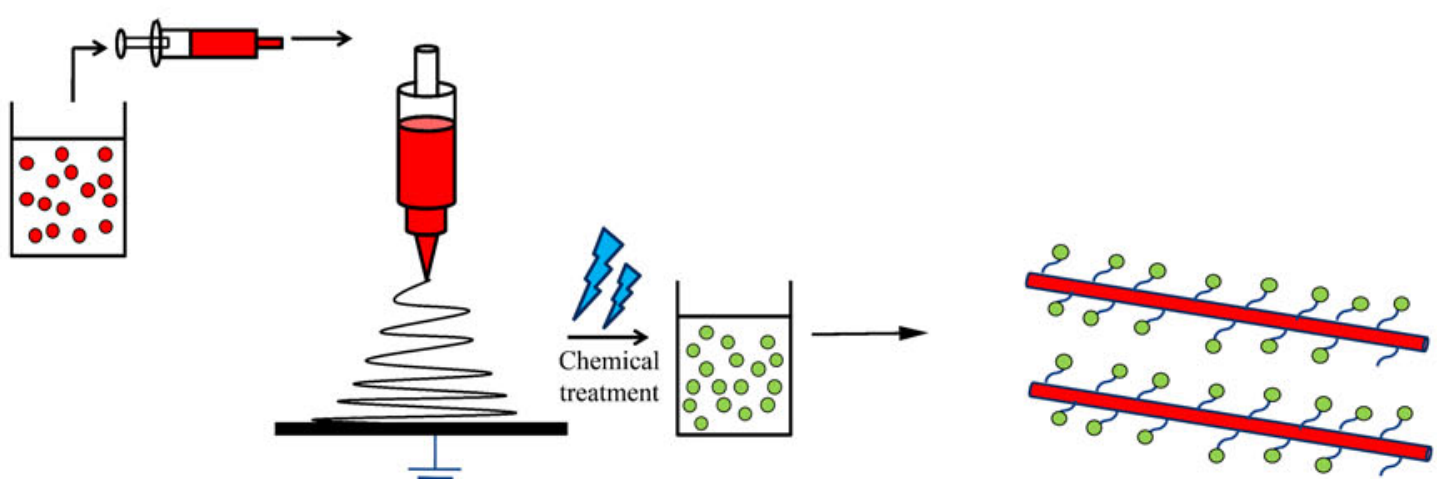

Fig. 4 Fabrication techniques of bioactive electrospun scaffolds. a physical adsorption; b blend electrospinning; c coaxial electrospinning; $\mathbf{d}$ covalent immobilization. 
solution $(46,47,53)$ are beneficial for improving protein stability. Futhermore, a recent study showed that hydroxyapatite (HAp) particles were able to preserve the activity of BMP2 loaded in electrospun PLGA scaffolds, as proteins can attach to these hydrophilic particles so as to escape the harsh electrospinning process (21).

A typical protein release profile from blend electrospun scaffolds is an initial burst release followed by a sustained release close to a linear mode $(24,44,46,54,55)$. The burst release usually occurs within $24 \mathrm{~h}$, regardless of polymer type for scaffolds preparation. This initial burst release may be related to the migration of protein during drying and storage steps, which localizes a certain fraction of protein molecules near the fiber surface (56). The high solubility and partition coefficients of the incorporated protein can lead to a rapid release through short diffusion pathways due to thermodynamic imbalances (33). After burst release, the protein release behavior is mainly driven by protein diffusion or the effect of polymer degradation and protein diffusion. For slowly degradable polymers, such as PCL, the protein release profile behaves as a relatively linear mode (56), whereas for PLGA, a polymer with relatively short degradation time, the protein release profile shows a sustained mode followed by an obvious increased release rate once the polymer starts to degrade $(21,54)$. The protein release profile can be modulated by additives loaded together with protein during blend electrospinning. The addition of hydrophilic additives, such as hydroxyapatite particles (21,54) and PEG (46), will improve the hydrophility of scaffolds and, hence, enhance water uptake of the scaffolds as well as accelerate protein release from electrospun scaffolds.

The first gene delivery using blend electrospinning approach was reported by Luu et al. (24). In this study, the authors mixed pCMV $\beta$ plasmid (7,164 bp) encoding bgalactosuchsidase with PLA-PEG-PLA tri-block copolymer and high molecular weight (75 kDa) PLGA (LA/GA = 75/25). Since then, many groups have used this approach to incorporate $b m p 2$ with different plasmids into electrospun scaffolds $(37,47)$. In this approach, the plasmid gene is able to withstand the electrospinning process because of the protection from complexation with vectors. Luu et al. (24) found that DNA kept its structural integrity after release out of PLGA scaffolds. Nie et al. (36) also showed that the incorporated $b m p 2$ was still capable of inducing BMP2 expression in vivo after 4 weeks.

Different from protein release, gene release shows two types of profiles from blend electrospun scaffolds, which might be related to different fiber compositions. Luu et al. (24) reported a burst release within $2 \mathrm{~h}$ followed by a sustained DNA release until 20 days using PLA-PEG block copolymers blended with different variations of PLGA, whereas others obtained a linear release profile up to
2 months from composite PLGA electrospun scaffolds $(37,57)$.

\section{Coaxial Electrospinning}

Coaxial electrospinning, also known as co-electrospinning, was first demonstrated by Sun et al. (58). In coaxial electrospinning, two solutions (i.e. polymer solution and biological solution) are coaxially and simultaneously electrospun through different feeding capillary channels in one needle to generate composite nano-fibers with core-shell structures (Fig. 4c). Coaxial electrospinning is a very dynamic process, and many factors, such as feeding rate of the inner and outer fluids, interfacial tension and viscoelasticity of the two solutions, affect the entrapment of components in the core part $(58,59)$. Although this technique was developed more than 10 years ago (60), the application of coaxial electrospinning to deliver biomolecules has only been explored since 5 years ago $(24,44)$ due to the complexity of this technique.

Recently, coaxial electrospinning has gained increased popularity in the protein delivery field because the produced core-shell fibers have great potential in preserving proteins during the electrospinning process. In addition, it provides homogeneous protein distribution throughout the fibers, and proteins can be delivered in a controlled manner due to the shell barrier (Fig. 5). Researchers have achieved encapsulation of different types of proteins in coaxially electrospun scaffolds, including BSA (56,61-63), lysozyme (62), platelet-derived growth factor-bb (PDGF-bb) (64,65), nerve growth factor (NGF) (66) and fibroblast growth factor (FGF) (67). These studies indicated that released growth factors had efficient bioactivity to stimulate corresponding cell growth. Some authors attribute this bioactivity preservation only to the superiority of coaxial electrospinning, as during coaxial electrospinning, the electric charges are located predominantly at the outer fiber surface so that the inner protein solutions are not charged at all (25). In contrast, we compared the effect of blend and coaxial electrospinning on protein activity by using alkaline phosphatase (ALP) as a model protein, and our results indicated that both electrospinning techniques depressed the biological activity of the incorporated ALP, suggesting that high voltage and contact with organic solvents are harmful to the loaded biomolecules; the ALP through coaxial electrospinning without PEG loaded maintained significantly lower enzyme activity than the one with PEG loaded regardless of electrospinning method (68).

The protein release profile from coaxial electrospun fibers also includes an initial burst release followed by a sustained release stage $(56,61,62,66,67)$, which is similar to the one from blend electrospun scaffolds. However, 
Fig. 5 Protein distribution and core-shell structure of coaxial electrospun fibers. a Laser scanning confocal microscopy images to visualize protein distribution in coaxial electrospun fibers. The panels in each image are as follows: upper left: fitclabeled protein (green); upper right: rhodamin B-labeled polymer (red); bottom left: natural light; bottom right: the merger of fitc and rhodamin B. b Transmission electron microscopy image to visualize the core-shell structure of the same coaxial electrospun fibers. Arrows indicate the core and shell parts within the fiber. a

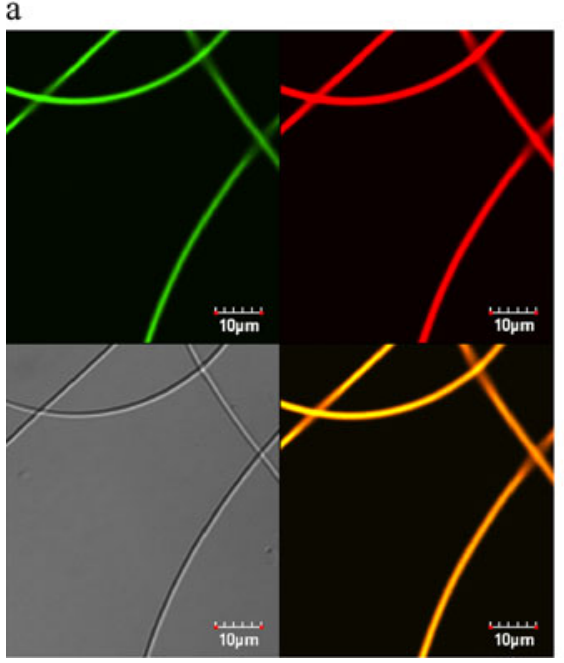

b

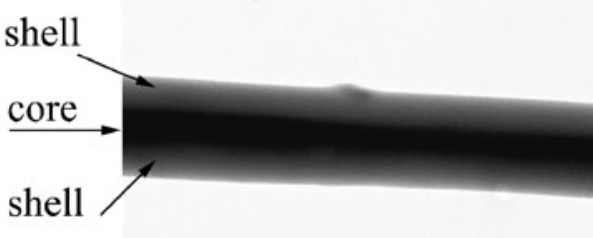

compared to blend electrospinning, the burst release from coaxial fibers is significantly lower, and the entire release profile is more sustained $(56,68)$, because core-shellstructured fibers provide a protein reservoir system with a barrier membrane that controls the protein diffusion rate (68).

To date, only a limited number of studies on gene delivery via coaxial electrospinning scaffolds has been published. Saraf et al. (69) incorporated pDNA into an aqueous poly(ethylene glycol) (PEG) solution to fabricate the core of fibers and loaded hyaluronic acid (HA) derivative of poly(ethylenimine) (PEI) as gene delivery vector into an organic sheath polymer solution of poly ( $\varepsilon$-caprolactone) (PCL) to form the shell part. Their results suggested that the plasmid diffusing out of the fiber cores could complex with the positively charged vector PEI-HA released from the fiber shells. In addition, the released gene-vector complex could sustainably transfect cells present on the scaffolds over 60 days with 15\% transfection efficiency on average. The authors concluded that transfection efficiency was related to the concentration and molecular weight of the core polymer PEG. However, the pDNA release was not directly measured in their study. Liao et al. (70) used core-shell fibers to deliver the adenovirus (Ad) encoding gene of green fluorescence protein (GFP) in vitro. They succeeded to detect cells expressing GFP for more than 30 days, and the cell transfection efficiency could reach over $80 \%$. However, the high transfection efficiency only sustained for 2 weeks, which is related to the initial burst release. Their results showed that different polymer compositions have different pore formation ability on the fiber surface, which contributed to different release profiles and cell transfection efficiencies.

\section{Covalent Immobilization}

Covalent immobilization immobilizes biomolecules onto the fiber surface via chemical bond, for instance, forming peptide bond through amino groups (71) (Fig. 4d). Compared to the above-mentioned strategies, this approach is predominantly used to improve the surface properties of electrospun fibers (72), but some researchers are applying this approach to deliver protein aiming to achieve controlled release profiles, because the release rate of the immobilized biomolecules can be controlled by the external enzymes.

Choi et al. (73) reported that BSA-immobilized nanofibers showed no obvious burst release, although the authors only observed the release within 1 week. Using the same strategy, they prepared electrospun scaffolds with epidermal growth factor (EGF) delivery and succeeded in effective application of these bioactive scaffolds in vivo (74).

Kim et al. (71) introduced a matrix metalloproteinases (MMPs)-cleavable linker between gene-vector complex and the electrospun scaffolds, so that gene release can be controlled by external MMPs cleavage. Their results showed that a fast gene release can be achieved in presence of MMP-responsive peptides, for which the maximum released amount was $82 \%$ within $12 \mathrm{~h}$, whereas less than $40 \%$ of incorporated gene was released if MMPs were absent.

So far, covalent immobilization is not a routine way to deliver protein or genes from electrospun scaffolds due to its technical complexity. In addition, some researchers also doubt the uniformity loss of the scaffolds during surface modification process (75), which might affect mechanical properties of the scaffolds. In addition, the manipulation of protein configuration and function by choosing specific 
binding sites in the protein molecule is still a big challenge. However, surface covalent immobilization represents an option to achieve delivery of multiple biomolecules in combination with the biomolecules directly incorporated within the scaffolds (11).

\section{CHALLENGES AND OUTLOOK}

Although electrospinning shows huge potential and promising application possibilities to prepare tissue engineering scaffolds with biomolecule delivery, challenges still exist for further application of such bioactive scaffolds, which includes concerns about (1) protein instability, (2) low gene transfection efficiency, and (3) difficulties in release kinetics control.

\section{Protein Instability}

Maintaining protein conformation within the scaffolds will be essential for further biomedical application of protein delivery from electrospun scaffolds, because the loss of conformation of a protein might not only be detrimental to the bioactivity and hence therapeutic potential, but also causes immunogenic effects related to exposure of nonnative peptide epitopes (76). Although it has been reported that protein released from freshly prepared electrospun scaffolds was capable of inducing various cellular responses $(21,42,45,54,65)$, indicating the preservation of protein activity after the electrospinning process, it is too easy to claim that proteins incorporated within electrospun scaffolds will behave similar to the virgin proteins. As aforementioned, the threat for protein instability regarding electrospun scaffolds might arise from either fabrication, storage or degradation period. Also, it needs to be mentioned that the instability of protein during storage and degradation period is a general problem for polymeric protein delivery system. Therefore, the development of methods to optimize protein stability during these three stages is a major challenge for effective protein delivery from electrospun scaffolds.

During the scaffold preparation process, high voltage and contact with organic solvents may be harmful to the growth factor activity $(42,53,77)$. Although using coaxial electrospinning and adding hydrophilic additives (e.g., PEG, hydroxyapatite) was reported to minimize the interaction between protein and organic phase $(21,42)$, the protein still loses $20 \%$ bioactivity due to the loss of $\alpha$-helix in secondary structure compared with virgin protein solution (68).

Once the scaffolds are prepared, normally they are lyophilized for storage before application. It has been recognized that protein stresses may also arise from the drying process without appropriate stabilizing excipients (78). As a result, it is wise to include protein stabilizer within the electrospun scaffolds to avoid the protein degradation during lyophilization. The commonly used lyoprotectants include sugars (e.g., sucrose) and polymers with relative high collapse temperature (e.g., dextran) (78). Some authors used PEG (56) or dextran (61) as protein stabilizer during coaxial electrospinning, but they rarely mentioned the effect of these additives on protein stability during lyophilization. Sucrose is suggested to be effective at inhibiting unfolding during lyophilization (78), but its effect on electrospun scaffold fabrication and protein stabilization still needs further investigation.

When the synthetic polymeric electrospun scaffolds start to degrade, the acidic microenvironment induced by hydrolysis products of polyesters is also likely to be destructive to growth factor integrity $(79,80)$. This is especially a serious concern for PLGA, which is attractive for biomolecule delivery because of its tailored degradation rate to achieve controlled release. The instability of incorporated proteins comes from deamidation at asparagine residues, peptide bond hydrolysis and acylation of protein primary amines (e.g., N-terminus, Lysine group) in degrading PLGA systems. All these instabilities are related to the acidic microclimate $\mathrm{pH}$ produced by the accumulation of acidic monomers and oligomers during PLGA degradation (80). In consequence, it is necessary to maintain the $\mathrm{pH}$ during scaffold degradation to stabilize the protein incorporated within PLGA delivering systems. Currently, there are two effective approaches to maintain $\mathrm{pH}$ within a PLGA protein delivery system. One is using hydrophilic polymer PEG as porogen in PLGA scaffolds to enhance acidic degraded products release (81), but this approach will decrease the mechanical properties of electrospun scaffolds, which might limit its further application. The other approach is adding poorly water-soluble basic salts such as $\mathrm{Mg}(\mathrm{OH})_{2}$ to neutralize acidic microenvironment during scaffolds degradation (82). However, it is interesting that the use of this approach is not widespread in spite of its apparent simplicity.

\section{Low Gene Transfection Efficiency}

Although many studies showed that it is feasible to deliver target genes at the desired tissue site via electrospun scaffold implantation $(24,36,47,71)$, the low gene transfection efficiency remains a drawback. Basically, the low efficiency is not only an obstacle for electrospun scaffolds with gene release, but also a key technical barrier for full exploitation of the potential of gene therapies. In order to improve gene transfection efficiency, viral vectors seem to be a straightforward option, as viral vectors have natural tropism for living cells. However, their immunogenic potential and the 
threat of disturbing normal gene function from retroviruses and adeno-associated viruses limits their further clinical application (83,84). In recent years, other options for improving transfection efficiency have been experimented with, including nano-scaled delivery carriers (85), gene gun (86), disulfide linkages in cationic polymers (87) and bioresponsive polymers (68). Unfortunately, those methods are difficult to combine with electrospun scaffolds.

The poor interactions between released gene particles and cells is another possible reason for the low gene transfer efficiency via electrospun scaffolds. It is known that the released gene dose has to reach a threshold to induce gene transfection in cells, as recent studies have demonstrated that low concentrations of released gene always yield a low transfection efficiency $(36,37)$.

\section{Release Kinetics Control}

In order to achieve an effective dose and a target release profile, it is necessary to use mathematical models to predict release kinetics on the basis of good estimates of the required composition, geometry, and dimensions of the biomolecular delivery system. A mechano-realistic mathematical model is based on equations that describe real phenomena, e.g. mass transport by diffusion, dissolution of biomolecules, and/or the transition of a polymer from a glassy to rubbery state (88). The mathematical modeling of biomolecule delivery from polymeric matrices has been clearly reviewed $(34,88)$. Among different models, a simple and useful empirical equation is the so-called power law equation (34):

$\mathrm{Mt} / \mathrm{M}_{\infty}=k \mathrm{t}^{\mathrm{n}}$,

where $\mathbf{M}_{\infty}$ is the amount of drug released after an infinite time, $k$ is a constant related to the structure and geometric characteristics of the system, and $\mathrm{n}$ is the release exponent indicating the mechanism of protein release (88). However, it needs to be mentioned that, in practice, the release kinetics are likely affected by many factors, including polymer swelling, polymer erosion, biomolecular dissolution/diffusion characteristics, biomolecules distribution inside the matrix, biomolecule/polymer ratio and system (34). Apparently, it is impossible for a single mathematic model to consider all variables. Therefore, deviation will always exist between theoretical prediction and practical realization. Furthermore, in vivo biomolecule delivery from degradable polymeric scaffolds will be strongly affected by the surrounding tissue environment (e.g. pH value and cellular tissue reaction). Nevertheless, there is no mathematical model available that estimates biomolecule release from biodegradable vehicles under physiological conditions. Consequently, it is necessary to design advanced mathematical models considering in vivo conditions.

\section{SUMMARY}

Tissue engineering is a promising research area for present and future regenerative medicine, and the fundamental concept behind tissue engineering is to utilize the body's natural biological response to tissue damage in conjunction with engineering principles (1). In order to achieve successful and efficient tissue engineering applications, there is an increasing demand for bioactive scaffolds that can provide more than only physical support for cells but also local release of biomolecules to direct tissue regeneration in the defect area. Growth factors and growth factor-coding genes are the most straightforward biological stimuli to promote tissue regeneration. Consequently, studies related to the controlled delivery of growth factors and genes from bioactive scaffolds show an exponential increase over the last decade. Bioactive scaffolds with growth factor or gene delivery can be prepared in the form of micro/nanospheres, hydrogel, as well as electrospun fibers. In recent years, electrospun fibrous scaffolds have attracted increasing attention due to the relative simplicity regarding the generation of fibrous scaffolds with nanoscale dimensions.

Electrospinning utilizes electrostatic forces to spin polymer solutions or melts into whipped jets, revealing continuous fibers with diameters from a few nanometers to micrometers after solvent evaporation in the spinning process. Because of the ultrathin fiber diameter, electrospun scaffolds are considered as an effective delivery system for biomolecules due to the stereological porous structure and high specific surface area. Biomolecules can be incorporated within electrospun scaffolds by physical adsorption, blend electrospinning, coaxial electrospinning as well as covalent immobilization after scaffolds fabrication. Although there has been a substantial number of studies dedicated to the methodology of preparing electrospun scaffolds to achieve biomolecules delivery, further studies are needed to improve the stability of incorporated protein, gene transfection efficiency as well as the accuracy of release kinetics control.

Until now, only a limited number of research efforts have focused on in vivo applications of electrospun scaffolds with protein or gene delivery. Consequently, more animal studies are needed to fully explore the potential of these bioactive scaffolds for clinical applications. Close cooperation between laboratory and clinics might eventually help to translate this promising technique from bench to bed, and it is likely that biomolecule delivery from electrospun scaffolds will provide therapeutic benefit in regenerative medicine in the near future. 


\section{ACKNOWLEDGMENTS}

This work is financially supported by Royal Netherlands Academy of Arts and Sciences (project no. PSA 08-PSA-M-02 \& CEP 09-CDP-020).

Open Access This article is distributed under the terms of the Creative Commons Attribution Noncommercial License which permits any noncommercial use, distribution, and reproduction in any medium, provided the original author(s) and source are credited.

\section{REFERENCES}

1. Porter JR, Ruckh TT, Popat KC. Bone tissue engineering: a review in bone biomimetics and drug delivery strategies. Biotechnol Prog. 2009;25(6):1539-60.

2. Langer R, Vacanti JP. Tissue engineering. Science. 1993;260 (5110):920-6.

3. Rosenberg MD. Cell guidance by alterations in monomolecular films. Science. 1963;139:411-2.

4. Ma Z, Kotaki M, Inai R, Ramakrishna S. Potential of nanofiber matrix as tissue-engineering scaffolds. Tissue Eng. 2005;11(12):101-9.

5. Martins A, Duarte ARC, Faria S, Marques AP, Reis RL, Neves NM. Osteogenic induction of hBMSCs by electrospun scaffolds with dexamethasone release functionality. Biomaterials. 2010;31 (22):5875-5885

6. Wang F, Li ZQ, Khan M, Tamama K, Kuppusamy P, Wagner WR, Sen CK, Guan JJ. Injectable, rapid gelling and highly flexible hydrogel composites as growth factor and cell carriers. Acta Biomater. 2010;6(6):1978-1991.

7. Murphy WL, Peters MC, Kohn DH, Mooney DJ. Sustained release of vascular endothelial growth factor from mineralized poly (lactide-co-glycolide) scaffolds for tissue engineering. Biomaterials. 2000;21(24):2521-7.

8. Moioli EK, Clark PA, Xin X, Lal S, Mao JJ. Matrices and scaffolds for drug delivery in dental, oral and craniofacial tissue engineering. Adv Drug Deliv Rev. 2007;59(4-5):308-24.

9. Tabata Y. The importance of drug delivery systems in tissue engineering. Pharm Sci Technol Today. 2000;3(3):80-9.

10. Varkey M, Gittens SA, Uludag H. Growth factor delivery for bone tissue repair: an update. Expert Opin Drug Deliv. 2004;1 (1):19-36.

11. Chen FM, Zhang M, Wu ZF. Toward delivery of multiple growth factors in tissue engineering. Biomaterials. 2010;31(24):6279-6308.

12. Lu Z, Zreiqat $\mathrm{H}$. The osteoconductivity of biomaterials is regulated by bone morphogenetic protein 2 autocrine loop involving alpha2betal integrin and mitogen-activated protein kinase/extracellular related kinase signaling pathways. Tissue Eng A. 2010;16(10):3075-84.

13. Roy K, Wang D, Hedley ML, Barman SP. Gene delivery with in-situ crosslinking polymer networks generates long-term systemic protein expression. Mol Ther. 2003;7(3):401-8.

14. Storrie H, Mooney DJ. Sustained delivery of plasmid DNA from polymeric scaffolds for tissue engineering. Adv Drug Deliv Rev. 2006;58(4):500-14.

15. Babensee JE, McIntire LV, Mikos AG. Growth factor delivery for tissue engineering. Pharm Res. 2000;17(5):497-504.

16. De Laporte L, Shea LD. Matrices and scaffolds for DNA delivery in tissue engineering. Adv Drug Deliv Rev. 2007;59(4-5):292-307.
17. Basmanav FB, Kose GT, Hasirci V. Sequential growth factor delivery from complexed microspheres for bone tissue engineering. Biomaterials. 2008;29(31):4195-204.

18. Censi R, Vermonden T, van Steenbergen MJ, Deschout H, Braeckmans K, De Smedt SC, et al. Photopolymerized thermosensitive hydrogels for tailorable diffusion-controlled protein delivery. J Control Release. 2009;140(3):230-6.

19. Abbas AO, Donovan MD, Salem AK. Formulating poly(lactide-coglycolide) particles for plasmid DNA delivery. J Pharm Sci. 2008;97 (7):2448-61.

20. Sill TJ, von Recum HA. Electrospinning: applications in drug delivery and tissue engineering. Biomaterials. 2008;29(13):1989-2006.

21. Nie H, Soh BW, Fu YC, Wang CH. Three-dimensional fibrous PLGA/HAp composite scaffold for BMP-2 delivery. Biotechnol Bioeng. 2008;99(1):223-34.

22. Hoare TR, Kohane DS. Hydrogels in drug delivery: progress and challenges. Polymer. 2008;49(8):1993-2007.

23. Li WJ, Laurencin CT, Caterson EJ, Tuan RS, Ko FK. Electrospun nanofibrous structure: a novel scaffold for tissue engineering. J Biomed Mater Res. 2002;60(4):613-21.

24. Luu YK, Kim K, Hsiao BS, Chu B, Hadjiargyrou M. Development of a nanostructured DNA delivery scaffold via electrospinning of PLGA and PLA-PEG block copolymers. J Control Release. 2003;89 (2):341-53

25. Pham QP, Sharma U, Mikos AG. Electrospinning of polymeric nanofibers for tissue engineering applications: a review. Tissue Eng. 2006;12(5):1197-211.

26. Yang F, Both SK, Yang X, Walboomers XF, Jansen JA. Development of an electrospun nano-apatite/PCL composite membrane for GTR/GBR application. Acta Biomater. 2009;5 (9):3295-304.

27. Murugan R, Ramakrishna S. Nano-featured scaffolds for tissue engineering: a review of spinning methodologies. Tissue Eng. 2006;12(3):435-47.

28. Yarin AL, Koombhongse S, Reneker DH. Bending instability in electrospinning nanofibers. J Appl Phys. 2001;89(5):3018-26.

29. Venugopal J, Low S, Choon AT, Ramakrishna S. Interaction of cells and nanofiber scaffolds in tissue engineering. J Biomed Mater Res B Appl Biomater. 2008;84(1):34-48.

30. Agarwal S, Wendorff JH, Greiner A. Progress in the field of electrospinning for tissue engineering applications. Adv Mater. 2009;21(32-33):3343-51.

31. Zeugolis DI, Khew ST, Yew ES, Ekaputra AK, Tong YW, Yung LY, et al. Electro-spinning of pure collagen nano-fibres-just an expensive way to make gelatin? Biomaterials. 2008;29(15):2293-305.

32. Dong Y, Liao S, Ngiam M, Chan CK, Ramakrishna S. Degradation behaviors of electrospun resorbable polyester nanofibers. Tissue Eng B Rev. 2009;15(3):333-51.

33. Huang X, Brazel CS. On the importance and mechanisms of burst release in matrix-controlled drug delivery systems. J Control Release. 2001;73(2-3):121-36.

34. Grassi M, Grassi G. Mathematical modelling and controlled drug delivery: matrix systems. Curr Drug Deliv. 2005;2(1):97-1 16.

35. Kootstra NA, Verma IM. Gene therapy with viral vectors. Annu Rev Pharmacol Toxicol. 2003;43:413-39.

36. Nie H, Ho ML, Wang CK, Wang CH, Fu YC. BMP-2 plasmid loaded PLGA/HAp composite scaffolds for treatment of bone defects in nude mice. Biomaterials. 2009;30(5):892-901.

37. Nie H, Wang CH. Fabrication and characterization of PLGA/ HAp composite scaffolds for delivery of BMP-2 plasmid DNA. J Control Release. 2007;120(1-2):111-21.

38. Cleland JL. Protein delivery from biodegradable microspheres. Pharm Biotechnol. 1997;10:1-43.

39. Vasir JK, Labhasetwar V. Biodegradable nanoparticles for cytosolic delivery of therapeutics. Adv Drug Deliv Rev. 2007;59 (8):718-28. 
40. Giteau A, Venier-Julienne MC, Aubert-Pouessel A, Benoit JP. How to achieve sustained and complete protein release from PLGA-based microparticles? Int J Pharm. 2008;350(1-2):14-26.

41. Shi Y, Huang G. Recent developments of biodegradable and biocompatible materials based micro/nanoparticles for delivering macromolecular therapeutics. Crit Rev Ther Drug Carrier Syst. 2009;26(1):29-84.

42. Yang Y, Li X, Qi M, Zhou S, Weng J. Release pattern and structural integrity of lysozyme encapsulated in core-sheath structured poly(DL-lactide) ultrafine fibers prepared by emulsion electrospinning. Eur J Pharm Biopharm. 2008;69(1):106-16.

43. Kowalczyk T, Nowicka A, Elbaum D, Kowalewski TA. Electrospinning of bovine serum albumin. Optimization and the use for production of biosensors. Biomacromolecules. 2008;9(7):2087-90.

44. Zeng J, Aigner A, Czubayko F, Kissel T, Wendorff JH, Greiner A. Poly(vinyl alcohol) nanofibers by electrospinning as a protein delivery system and the retardation of enzyme release by additional polymer coatings. Biomacromolecules. 2005;6(3):1484-8.

45. Yang Y, Li X, Cui W, Zhou S, Tan R, Wang C. Structural stability and release profiles of proteins from core-shell poly (DLlactide) ultrafine fibers prepared by emulsion electrospinning. J Biomed Mater Res A. 2008;86(2):374-85.

46. Li Y, Jiang H, Zhu K. Encapsulation and controlled release of lysozyme from electrospun poly(epsilon-caprolactone)/poly(ethylene glycol) non-woven membranes by formation of lysozyme-oleate complexes. J Mater Sci Mater Med. 2008;19(2):827-32.

47. Li C, Vepari C, Jin HJ, Kim HJ, Kaplan DL. Electrospun silkBMP-2 scaffolds for bone tissue engineering. Biomaterials. 2006;27(16):3115-24.

48. Schneider A, Wang XY, Kaplan DL, Garlick JA, Egles C. Biofunctionalized electrospun silk mats as a topical bioactive dressing for accelerated wound healing. Acta Biomater. 2009;5 (7):2570-8.

49. Kim BS, Oh JM, Kim KS, Seo KS, Cho JS, Khang G, et al. BSAFITC-loaded microcapsules for in vivo delivery. Biomaterials. 2009;30(5):902-9.

50. Knoll D, Hermans J. Polymer-protein interactions. Comparison of experiment and excluded volume theory. J Biol Chem. 1983;258 (9):5710-5.

51. Michel R, Pasche S, Textor M, Castner DG. Influence of PEG architecture on protein adsorption and conformation. Langmuir. 2005;21(26):12327-32.

52. Wang Y, Annunziata O. Comparison between protein-polyethylene glycol (PEG) interactions and the effect of PEG on protein-protein interactions using the liquid-liquid phase transition. J Phys Chem B. 2007;111(5):1222-30.

53. Casper CL, Yamaguchi N, Kiick KL, Rabolt JF. Functionalizing electrospun fibers with biologically relevant macromolecules. Biomacromolecules. 2005;6(4):1998-2007.

54. Fu YC, Nie H, Ho ML, Wang CK, Wang CH. Optimized bone regeneration based on sustained release from three-dimensional fibrous PLGA/HAp composite scaffolds loaded with BMP-2. Biotechnol Bioeng. 2008;99(4):996-1006.

55. Chew SY, Wen J, Yim EK, Leong KW. Sustained release of proteins from electrospun biodegradable fibers. Biomacromolecules. 2005;6(4):2017-24.

56. Zhang YZ, Wang X, Feng Y, Li J, Lim CT, Ramakrishna S. Coaxial electrospinning of (fluorescein isothiocyanate-conjugated bovine serum albumin)-encapsulated poly(epsilon-caprolactone) nanofibers for sustained release. Biomacromolecules. 2006;7(4):1049-57.

57. Liang D, Luu YK, Kim K, Hsiao BS, Hadjiargyrou M, Chu B. In vitro non-viral gene delivery with nanofibrous scaffolds. Nucleic Acids Res. 2005;33(19):e170.

58. Sun ZC, Zussman E, Yarin AL, Wendorff JH, Greiner A. Compound core-shell polymer nanofibers by co-electrospinning. Adv Mater. 2003;15(22):1929-32.
59. Chakraborty S, Liao IC, Adler A, Leong KW. Electrohydrodynamics: a facile technique to fabricate drug delivery systems. Adv Drug Deliv Rev. 2009;61(12):1043-54.

60. Doshi J, Reneker DH. Electrospinning process and applications of electrospun fibers. J Electrostat. 1995;35:151-60.

61. Jiang H, Hu Y, Zhao P, Li Y, Zhu K. Modulation of protein release from biodegradable core-shell structured fibers prepared by coaxial electrospinning. J Biomed Mater Res B Appl Biomater. 2006;79(1):50-7.

62. Jiang H, Hu Y, Li Y, Zhao P, Zhu K, Chen W. A facile technique to prepare biodegradable coaxial electrospun nanofibers for controlled release of bioactive agents. J Control Release. 2005;108(2-3):237-43.

63. Li XQ, Su Y, Chen R, He CL, Wang HS, Mo XM. Fabrication and properties of core-shell structure P(LLA-CL) nanofibers by coaxial electrospinning. J Appl Polym Sci. 2009;111(3):1564-70.

64. Liao IC, Chew SY, Leong KW. Aligned core-shell nanofibers delivering bioactive proteins. Nanomed. 2006;1(4):465-71.

65. Li H, Zhao CG, Wang ZX, Zhang H, Yuan XY, Kong DL. Controlled release of PDGF-bb by coaxial electrospun dextran/poly (L-lactide-co-epsilon-caprolactone) fibers with an ultrafine core/shell structure. J Biomater Sci Polym Ed. 2010;21(6):803-819.

66. Wang JG, Liu JJ, Fan CY, Mo XM, He CL, Chen F. Preparation of coaxial electrospinning nanofibers for nerve growth factor delivery. J Clin Rehab Tiss Eng Res. 2008;12(23):4440-4.

67. Sahoo S, Ang LT, Goh JC, Toh SL. Growth factor delivery through electrospun nanofibers in scaffolds for tissue engineering applications. J Biomed Mater Res A. 2009;93A(4):1539-50.

68. Ji W, Yang F, van den Beucken JJ, Bian Z, Fan M, Chen Z, et al. Fibrous scaffolds loaded with protein prepared by blend or coaxial electrospinning. Acta Biomater. 2010;6(11):4199-207.

69. Saraf A, Baggett LS, Raphael RM, Kasper FK, Mikos AG. Regulated non-viral gene delivery from coaxial electrospun fiber mesh scaffolds. J Control Release. 2010;143(1):95-103.

70. Liao IC, Chen S, Liu JB, Leong KW. Sustained viral gene delivery through core-shell fibers. J Control Release. 2009;139(1):48-55.

71. Kim HS, Yoo HS. MMPs-responsive release of DNA from electrospun nanofibrous matrix for local gene therapy: in vitro and in vivo evaluation. J Control Release. 2010;145(3):264-71.

72. Li W, Guo Y, Wang H, Shi D, Liang C, Ye Z, et al. Electrospun nanofibers immobilized with collagen for neural stem cells culture. J Mater Sci Mater Med. 2008;19(2):847-54.

73. Choi JS, Yoo HS. Electrospun nanofibers surface-modified with fluorescent proteins. J Bioact Compat Polym. 2007;22(5):508-24.

74. Choi JS, Leong KW, Yoo HS. In vivo wound healing of diabetic ulcers using electrospun nanofibers immobilized with human epidermal growth factor (EGF). Biomaterials. 2008;29(5):587-96.

75. Ma ZW, Kotaki M, Ramarkrishna S. Surface modified nonwoven polysulphone (PSU) fiber mesh by electrospinning: a novel affinity membrane. J Membr Sci. 2006;272(1-2):179-87.

76. van der Walle CF, Sharma G, Ravi Kumar M. Current approaches to stabilising and analysing proteins during microencapsulation in PLGA. Expert Opin Drug Deliv. 2009;6(2):177-86.

77. van de Weert M, Hennink WE, Jiskoot W. Protein instability in poly(lactic-co-glycolic acid) microparticles. Pharm Res. 2000;17 (10):1159-67.

78. Carpenter JF, Pikal MJ, Chang BS, Randolph TW. Rational design of stable lyophilized protein formulations: some practical advice. Pharm Res. 1997;14(8):969-75.

79. Estey T, Kang J, Schwendeman SP, Carpenter JF. BSA degradation under acidic conditions: a model for protein instability during release from PLGA delivery systems. J Pharm Sci. 2006;95(7):1626-39.

80. Houchin ML, Topp EM. Chemical degradation of peptides and proteins in PLGA: a review of reactions and mechanisms. J Pharm Sci. 2008;97(7):2395-404. 
81. Jiang W, Schwendeman SP. Stabilization and controlled release of bovine serum albumin encapsulated in poly(D, L-lactide) and poly (ethylene glycol) microsphere blends. Pharm Res. 2001;18(6):878-85.

82. Zhu G, Mallery SR, Schwendeman SP. Stabilization of proteins encapsulated in injectable poly (lactide- co-glycolide). Nat Biotechnol. 2000;18(1):52-7.

83. Mahr JA, Gooding LR. Immune evasion by adenoviruses. Immunol Rev. 1999;168:121-30.

84. Noguchi P. Risks and benefits of gene therapy. N Engl J Med. 2003;348(3):193-4.

85. Fernandez CA, Rice KG. Engineered nanoscaled polyplex gene delivery systems. Mol Pharm. 2009;6(5):1277-89.

86. Yang NS, Burkholder J, Roberts B, Martinell B, McCabe D. In viwo and in vitro gene transfer to mammalian somatic cells by particle bombardment. Proc Natl Acad Sci USA. 1990;87(24):9568-72.
87. Lin C, Engbersen JF. The role of the disulfide group in disulfide-based polymeric gene carriers. Expert Opin Drug Deliv. 2009;6(4):421-39.

88. Siepmann J, Siepmann F. Mathematical modeling of drug delivery. Int J Pharm. 2008;364(2):328-43.

89. Grafahrend D, Calvet JL, Klinkhammer K, Salber J, Dalton PD, Moller M, et al. Control of protein adsorption on functionalized electrospun fibers. Biotechnol Bioeng. 2008;101(3):609-21.

90. Sakai S, Yamada Y, Yamaguchi T, Ciach T, Kawakami K. Surface immobilization of poly(ethyleneimine) and plasmid DNA on electrospun poly(L-lactic acid) fibrous mats using a layer-by-layer approach for gene delivery. J Biomed Mater Res A. 2009;88(2):281-7.

91. Park Y, Kang E, Kwon OJ, Hwang T, Park H, Lee JM, et al. Ionically crosslinked $\mathrm{Ad} /$ chitosan nanocomplexes processed by electrospinning for targeted cancer gene therapy. J Control Release. 2010. doi:10.1016/j.jconrel.2010.06.027. 